\title{
Työssä kehittyminen tietotyöntekijän oikeutena ja velvollisuutena
}

\begin{abstract}
10
Onko työssä kehittyminen työntekijän oikeus vai työnantajan asettama velvollisuus? Tietotyössä se on osa psykologista sopimusta, johon kuuluu kaksisuuntaisuus ja vastavuoroisuus. Yleensä työntekijä kuitenkin itse huolehtii omien oikeuksiensa toteutumisesta, kuten lisäkouluttautumisesta.
\end{abstract}

"Tiettyjä asiantuntijoita, jotka ovat äärimmäisen tärkeitä meidän kilpailukyvyn kannalta, kyllä houkuttaa tän tyyppinen firma. Ja silloin meidän pitäis osata tehdä työn sisältö täällä sellaiseksi, ett sen tyyppiset asiantuntijat kokevat kehittyvänsä koko ajan ja saavansa siitä riittävän kompensaation."

EDELLÄ SITEERATUN telealan organisaation henkilöstöjohtajan mukaan työssä kehittymisen mahdollisuus on oiva tapa sitouttaa osaavia työntekijöitä organisaatioon. Organisaatio tarvitsee osaajia pärjätäkseen kilpailussa, ja asiantuntijat haluavat kehittyä työssään. Työssä kehittyminen ja kouluttautuminen ovat nykyajan työelämässä jatkuvasti läsnä. Työntekijöiden kehittyminen palvelee paitsi työntekijää itseään, myös työnantajaa ja yhteiskuntaa. Työnanta- jalle se voi olla menestystekijä, ja työntekijälle kehittyminen voi merkitä työn mielekkyyden kasvamista tai mahdollisuuksia edetä uralla. Suomen kilpailukyvyn ja hyvän työelämän yhtenä taustaedellytyksenä on työ- ja elinkeinoministeriön (2012) Työelämän kehittämisstrategian mukaan osaava työvoima. Tämän vuoksi koko työvoiman työuran aikaista osaamista tulee kehittää, ja työssä oppimisen ja työn tekemisen tulisi muodostaa saumaton kokonaisuus. Myös opetusministeriö (2010) näkee Elinikäisen oppimisen ohjelmajulistuksessaan työuran aikaisen oppimisen ja kehittymisen olevan edellytys myös työurien pidentämiselle.

Poliittisissa lausunnoissa työvoiman kehittymisen arvo on selvä, mutta onko kehittyminen keskeinen osa työn arkea ja työsuhdetta? Työntekijän ja työn- 
antajan välinen suhde on vaihtokauppaa, jossa työpanosta ja osaamista vaihdetaan palkkaan ja muihin etuihin. Perinteisen psykologisen sopimuksen, jonka mukaan työnantaja on taannut hyvin tehdyn työn vastineeksi sen jatkuvuuden, on sanottu olevan murroksessa. Uusien psykologisten sopimusten pääsisällöksi ja -lupaukseksi onkin kuvailtu itsensä kehittämisen mahdollisuutta ja sitä kautta parempaa työllistyvyyttä. Kehittyminen olisi siis työntekijöiden oikeus, jolla korvataan perinteiseen psykologiseen sopimukseen liitettyä työn jatkuvuuden lupausta. (Rousseau 1995; Alasoini 2006, 2012). Tarkastelen tässä artikkelissa tämän ns. työllistyvyys-teesin valossa työssä kehittymisen merkitystä tietotyöntekijöiden psykologisissa sopimuksissa. Kysyn, (1) koetaanko työssä kehittyminen ja oppiminen työntekijän oikeudeksi vai velvollisuudeksi, ja (2) ovatko työnantajat aktiivisia tarjoamaan työntekijöille heidän tarpeitaan palvelevia kehittymismahdollisuuksia vai onko työssä oppimisen lähtökohtana pikemminkin organisaation muuttuvat tarpeet.

\section{TIETOTYÖSSÄ KEHITTYMINEN JA KOULUTTAUTUMINEN}

Työelämä edellyttää jatkuvaa kehittymistä ja oppimista. Työssä kehittyminen ja oppiminen käsittävät työtaitojen kehittämisen epämuodollisesti työnteon myötä, työn arjessa. Varsinainen työpaikkakoulutus puolestaan määritellään työelämän instituutioiden järjestämiksi koulutuksiksi (ks. esim. Tulkki \& Honkanen 1998).

Työn tietoistuminen on osaltaan muuttanut osaamisvaatimuksia työssä. Tietotyöllä tarkoitetaan tiedon käsittelyä, välittämistä ja tuottamista sisältävää työtä, joka on yleensä luonteeltaan itsenäistä ja luovia osia sisältävää, ja johon vaaditaan korkea koulutus. Usein tietotyössä keskeisenä työvälineenä on tietotekniikka. (Blom ym. 2001: Alvesson 2004; ks. myös Ojala \& Hautaniemi 2012). Käytännössä tietotyöntekijät työskentelevät erilaisissa asiantuntijatehtävissä, joiden ytimessä on luova ongelmanratkaisu.

Työn tietoistumisen on sanottu aiheuttavan sekä työn sisällöllistä köyhtymistä että osaamistarpeiden kasvamista ja monipuolistumista. Tietotyössä työntekijöiden jatkuva kehittyminen on välttämätöntä työn nopean ja jatkuvan muutoksen vuoksi. Chris Bennerin mukaan olennaisin, vaikkakin vähälle huomiolle jäänyt puoli muutoksessa on osaamistarpeiden muuttumisen vauhti. Etenkin tietotekniikan nopea kehittyminen aiheuttaa taitojen "vanhenemista" niin nopeassa tahdissa, että peruskoulutus ei pysy muutosten tahdissa. (Benner 2002, 26-29.) Tietotyössä työntekijä ei ole valmis asiantuntija työhön tullessaan, vaan asiantuntemus hankitaan työssä kehittymisen myötä. Martinin ym. (1998) tutkimuksen mukaan tietotyöläiset kokevat työssä kehittymisen merkityksen eri tavalla kuin tuotantotyöläiset. Tuotantotyöläiset toivoivat voivansa työssä oppimisen avulla pitää nykyisen työpaikkansa, kun taas tietotyöntekijät katsoivat asiaa laajemmalla perspektiivillä ja toivoivat taitojen kehittymisen lisäävän heidän markkina-arvoaan myös nykyisen organisaation ulkopuolella.

Työssä kehittyminen ja oppiminen ovat suomalaisille työntekijöille tärkeitä, jopa tärkeämpiä kuin parempaan asemaan eteneminen. Tilastokeskuksen vuoden 2008 Työolotutkimuksen mukaan nykyisessä työssä kehittymistä piti erittäin tärkeänä lähes puolet vastaajista, kun vain joka kymmenes piti parempaan asemaan etenemistä erittäin tärkeänä. (Lehto 2010.) Toisaalta oppiminen koetaan myös raskaaksi: Työolotutkimuksen mukaan jatkuvaa uuden asioiden omaksumista piti työssä viihtymistä heikentävänä tekijänä lähes viidennes (16\%) vastaajista, ja määrä on ollut kasvussa 1990-luvulta lähtien (Lehto \& Sutela 2008, 196).

Etenkin nuoret, niin sanottuun Y-sukupolveen kuuluvat työntekijät, arvostavat työssä oppimisen mahdollisuutta, koska se mahdollistaa omien taitojen kehittymisen ja sitä kautta työmarkkinoilla pärjäämisen. Toisaalta kouluttautumismahdollisuudet voivat myös lisätä sitoutumista nykyiseen työnantajaan. (Sturges ym. 2002; Sieben 2007.) Elinikäisen oppimisen ja kouluttautumisen on sanottu olevan merkittävä työmarkkinakelpoisuuden määre ja keino hallita yksilöllisiä riskejä, kuten työttömyyttä (Suikkanen ym. 2006, 119). Kouluttautuminen on tärkeää, koska oppilaitokset eivät tuota valmiita työntekijöitä nopeasti muuttuviin työtehtäviin. Siten myös työnantajien edun mukaista olisi taata työnte- 
kijöille sellaiset työolot ja -ehdot, että ammattitaitoa on mahdollista kehittää (Aro 2006, 217-218).

Kehittymisen ja oppimisen esittäminen työntekijän etuna on hyvin voimakas diskurssi, joka kyseenalaistetaan vain harvoin. Työpaikoilla voidaan kuitenkin myös vastustaa jatkuvaa kehityksen ja oppimisen vaatimusta monin eri tavoin ja vaatimusten voidaan nähdä aiheuttavan stressiä ja sitoutumisen vähentymistä. (Järvensivu \& Koski 2012.) Etenkin tietointensiiviset organisaatiot ovat kuitenkin hyvin riippuvaisia työntekijöiden kehittymisestä ja tietopääomasta, mikä on tärkeä osa organisaation aineetonta pääomaa. Työntekijöiden tiedot, taidot ja osaaminen ovat tärkeä tekijä tuloksellisuuden kannalta, ja tietointensiivisissä organisaatioissa se voi olla jopa organisaation ainut pääoma. Organisaatiot eivät kuitenkaan omista osaamista, vaan se on työntekijöiden hallussa. Organisaatioiden tulisi siten pitää huolta tämän pääoman säilymisestä organisaatiossa eli sitouttaa erityisesti avaintyöntekijöitä. (Jääskeläinen 2011; Alvesson 2004).

Osaamisen kehittymisestä voivat hyötyä siis sekä työntekijä että työnantaja. Tämä kaksisuuntainen hyöty tekee osaamisen kehittämisestä erityisen osan psykologista sopimusta: se voidaan nähdä sekä työntekijän oikeutena, velvollisuutena että samanaikaisesti molempina.

\section{Psykologinen sopimus ja työssä kehittyminen}

Työssä kehittymisen mahdollisuus on tärkeä osa psykologista sopimusta, jonka Denise Rousseau (1995) määrittelee työntekijän subjektiiviseksi käsitykseksi työsuhteeseen kuuluvista oikeuksista ja velvollisuuksista. Psykologinen sopimus voi olla luonteeltaan taloudelliseen vaihtoon perustuva transaktionaalinen sopimus tai molemminpuoliselle lojaaliudelle perustuva relationaalinen sopimus. Näiden kahden mallin piirteet yhdistyvät tasapainotetussa psykologisessa sopimuksessa, johon kuuluu olennaisena osana mahdollisuus työssä oppimiseen ja kehittymiseen ja niiden avulla työuralla eteneminen yhteen työnantajaan kiinnittymisen sijaan. (Rousseau 1995; Conway \& Briner 2005.)

Psykologisen sopimuksen teoria versoo sosiaalisen vaihdon teoriasta, jonka olennainen osa on luottamuksen lisäksi vaihdon vastavuoroisuus (Blau 1964). Psykologisen sopimuksen teorian mukaan työntekijällä on odotuksia, jotka hän toivoo työnantajan täyttävän vastineeksi työpanoksestaan. Työnantajan lupauksien pitäminen luo pohjan luottamukselliselle vaihtosuhteelle ja "käynnistää" vastavuoroisuuden. Tutkimuksissa on havaittu, että työnantajat ja työntekijät näkevät vastavuoroisuuden tärkeänä osana psykologisen sopimuksen toimintaa (Rousseau 1995; Coyle-Shapiro \& Kessler 2002; Parzefall 2008.)

Työssä kehittyminen on yksi työsuhteen psykologisen sopimuksen vaihdannan välineistä. Työntekijöiden odotukset, jotka tämä toivoo työnantajan toteuttavan, voidaan jakaa kolmen eri "tason" vaihdantaan: taloudelliseen, sosio-emotionaaliseen ja kehittymisen tasoon. Työntekijän odotuksiin kehittymismahdollisuuksista vaikuttaa esimerkiksi se, miten pitkään hän on ollut työssä samalla työnantajalla, ja miten paljon työnantaja on sinä aikana tarjonnut kehittymismahdollisuuksia. (Bal ym. 2010; De Vos ym. 2003.)

Työssä kehittymistä psykologisen sopimuksen osana on vaihdannan logiikan lisäksi tutkittu toimijuuden kautta. Osa tutkimuksista näkee työntekijöiden reagoivan työnantajansa toimiin ja työelämän yleiseen tilaan. Esimerkiksi Flood ja kumppanit (2001) esittävät, että kun työntekijän odotukset täyttyvät eli he kokevat työnantajansa täyttäneen velvollisuutensa, työntekijät reagoivat haluamalla täyttää myös oman osuutensa sopimuksesta. Floodin ym. mukaan tietotyöntekijät sitoutuvat organisaatioon, joka tarjoaa kiinnostavaa ja haastavaa työtä, mikä auttaa työntekijää kehittämään osaamistaan. Toiset tutkimukset sen sijaan näkevät työntekijät psykologisen sopimuksen suhteen aloitteellisina ja aktiivisina toimijoina. Työntekijät käyttävät myös valtaa neuvotellessaan sopimuksista. (Seeck \& Parzefall 2008.) Työntekijät ovat aktiivisia toimijoita etenkin kehittymismahdollisuuksien suhteen. Vaikka työnantajat eivät aktiivisesti tarjoa heille mahdollisuuksia kehittymiseen, työntekijät haluavat kehittymismahdollisuuksia turvatakseen työllistymisensä myös jatkossa. (Martin ym. 1998.)

Myös vaihdon ja toimijuuden kautta ajateltuna työssä kehittyminen saa kaksoisluonteen: kenen ”va- 
luuttaa" kehittyminen on ja kuka on aktiivinen toimija kehittymisen tarjoamisessa tai toivomisessa? Vastavuoroisuus ja toimijuus liittyvät molemmat psykologisen sopimuksen toimintaan ja rakentumiseen. Tässä artikkelissa olen kiinnostunut myös sopimuksen sisällöstä eli sopimukseen kuuluvista oikeuksista ja velvollisuuksista. Psykologisen sopimuksen sisältöjen on sanottu muuttuneen ja perinteisen, relationaalisen sopimuksen käyneen harvinaisemmaksi. Sisällön on esitetty muuttuneen kohti tasapainotettua mallia, jossa etenkin työssä kehittymisellä ja oppimisella olisi merkittävä osuus. Ne paikkaisivat työn vähentynyttä turvallisuutta eli yhdessä organisaatiossa tehtyjen pitkien työurien muuttumista harvinaisemmiksi. Työssä kehittymisen myötä työntekijän työllistyvyys olisi siis parempi nykyisen työsuhteen mahdollisesti päättyessä (Rajan 1997).

Tätä ns. työllistyvyys-teesiä on suomalaisessa kontekstissa tutkinut etenkin Tuomo Alasoini (esim. 2006; 2012). Alasoinin mukaan myös suomalaisen työelämän psykologisessa sopimuksessa ja sen vaihdannassa on tapahtunut suuri muutos 1990-luvun jälkeen. Työn mielekkyys on heikentynyt perinteisen psykologisen sopimuksen murentumisen takia eli työsuhteiden ei koeta tarjoavan työntekijöille enää entisenlaista turvallisuutta ja jatkuvuutta. Työllistyvyys-teesin mukaisesti Alasoini esittää tämän murtumisen paikkaamista sillä, että työnantajat korvaisivat turvallisuuden lupaukset takaamalla työntekijöille mahdollisuuksia kehittää osaamistaan. Osaamisen kehittäminen olisi siis työntekijöiden saama vastine organisaatiolle tekemästään työstä eli työntekijöillä olisi oikeus tähän vastineeseen.

Joidenkin tutkimusten mu-

kaan psykologinen sopimus on muuttunut jo niin paljon, että työntekijöiden toiveissa ei edes olisi enää pitkä ja muuttumaton ura yhden työnantajan palveluksessa, vaan taitojen kehittymisen avulla uraa halutaan rakentaa (Smithson \& Lewis 2000; Martin, Staines \& Pate 1998). Kehittyminen on näiden tutki- musten mukaan paitsi työnantajapuolen lupaus myös työntekijöiden perustavanlaatuinen oikeus ja psykologisen sopimuksen merkittävä osa.

Ajatusta turvallisuuden ja työn jatkumisen korvaamisesta työllistyvyydellä on myös vastustettu. Esimerkiksi Yehuda Baruch'n (2001) mukaan koko idea on kestämätön jo siksi, että työnantajapuolen on mahdotonta saada työntekijät vakuuttumaan sen eduista. Vaikka kehittyminen on myös työntekijöiden intressinä, Baruch'n mielestä työntekijöillä on tarve sitoutumiseen ja molemminpuoliseen lojaalisuuteen, eivätkä lupaukset työllistyvyydestä täytä näitä tarpeita.

\section{TUTKIMUSAINEISTO JA -METODI}

Tutkimuksen aineisto koostuu 42 teemahaastattelusta, joista 24 on tietotyöntekijöiden ja loput 18 heidän esimiestensä haastatteluita. ${ }^{1}$

Esimiesten käsitykset jäävät usein psykologisen sopimuksen tutkimuksessa syrjään (Conway \& Briner 2005, ks. kuitenkin esim. Coyle-Shapiro \& Kessler 2002). Psykologinen sopimus on työntekijän subjektiivinen käsitys omaa työsuhdettaan koskevista oikeuksista ja velvollisuuksista eli käsitys siitä, mitä hänelle on luvattu. Sopimusta ei varsinaisesti neuvotella vaan se syntyy, kun työntekijä katsoo hänelle luvatun tiettyjä etuja tietyllä panostuksella. (Rousseau 1995.) Esimiehet eivät ole siis varsinaisia sopimusosapuolia, vaan organisaation edustajia sopimuksen rakentumisessa siinä mielessä, että työntekijät voivat ajatella näillä olevan oikeuden luvata etuja, ja heidän toimintansa vaikuttaa siten sopimukseen sisältyviin odotuksiin (Rousseau 1995; De Vos ym. 2003). Lisäksi tutkittaessa sopimuksen vastavuoroisuutta, kuten tässäkin tutkimuksessa, on syytä ottaa huomioon myös työnantajan toiveet ja odotukset työntekijöiden velvollisuuksien suhteen.

Aineisto on kerätty neljässä merkittävässä suomalaisessa tietointensiivisessä organisaatiossa. Ensimmäinen tutkittava organisaatio on teleoperaattorin asiakaspalveluyksikkö, joka koostuu help desk- ja con- 
tact center -osastoista (jatkossa ja aineisto-otteissa yhteisesti call center.) Call centerissä tehtiin yhteensä kolmetoista haastattelua, joista esimiesten haastatteluita oli viisi. Toinen esimerkkiorganisaatio on globaalin teollisuusyrityksen tutkimus- ja tuotekehitysyksikkö (aineisto-otteissa "T\&K”.) Yksikössä haastateltiin yhteensä seitsemän työntekijää, joista esimiesasemassa oli neljä. Kolmas organisaatio on suurehkon vakuutusalan yrityksen paikallisyksikkö (aineistootteissa "vakuutus".) Haastatteluja tehtiin yhteensä 10, esimiestehtävissä haastatelluista oli viisi. Viimeinen esimerkki on aikuiskoulutusalan organisaatio (aineisto-otteissa "koulutus"), jossa haastateltiin 12 työntekijää, joista neljä oli esimiehiä.

Haastattelujen kattoteemana oli työntekijöiden hyvinvointi, organisaation menestys ja näiden keskinäinen suhde. Haastatteluissa käsiteltiin monipuolisesti työhyvinvoinnin teemoja. Kehittyminen ja kouluttautuminen sekä uralla eteneminen tulivat esiin useiden teemojen yhteydessä, ja niitä käsiteltiin myös erillisinä kysymyksinä. Analysoin aineistoa teoriaohjaavan sisällönanalyysin keinoin (Tuomi \& Sarajärvi 2002; Krippendorf 2004). Kun aineistolähtöisessä analyysissä kysymykset kehittyvät aineiston pohjalta, teoriaohjaavassa sisällönanalyysissä, nimensä mukaisesti, aineistoa tarkastellaan valitun teorian kautta. Tämä ei kuitenkaan tarkoita pelkkää teorian testaamista, vaan myös aineiston tuomille uusille kysymyksille jätetään tilaa. (Tuomi \& Sarajärvi 2002.) Käytännössä analyysi alkoi aineiston teemoittelusta, jolloin erottelin siitä kaikki työssä kehittymistä, oppimista ja kouluttautumista koskevat puheenvuorot, erikseen työntekijöiden ja esimiesasemassa olevien ryhmissä. Tämän jälkeen lähdin edelleen jakamaan näitä teemoja uudelleen alaryhmiin; esimerkiksi omiksi ryhmikseen ne, jotka näkevät kehittymisen tarpeen tulevan työntekijöiltä itseltään ja niihin, joiden mukaan vaatimukset tulevat organisaatiolta, sekä hyötyihin työntekijöiden ja organisaation kannalta. Tutkimuksen analyysiyksikkönä on siten puheenvuoro tai sen osa, jossa haastateltava kertoo työssä kehittymisestä ja kouluttautumisesta ja suhteestaan niihin.

\section{TULOKSET}

Seuraavaksi analysoin esimiesten ja heidän alaistensa käsityksiä työssä kehittymisestä ja kouluttautumisesta. Tarkastelen kehittymistä ja kouluttautumista psykologisen sopimuksen osana: oikeutena ja vaatimuksena. Analysoin ensin organisaation tarpeita, toisena työntekijöiden toiveita ja viimeisenä vastavuoroisuuden toteutumisen haasteita ja mahdollisuuksia.

\section{Organisaation tarpeet ja työntekijän velvollisuudet}

On melko itsestään selvä lähtökohta, että organisaatiot tarvitsevat osaavaa henkilökuntaa toimiakseen tehokkaasti ja tuloksellisesti. Tästä lähtökohdasta kehittymisen koetaan ja perustellaan olevan työntekijän psykologiseen sopimukseenkin kuuluva perustavanlaatuinen velvollisuus, joka on edelleen korostunut tietotyön kovan kilpailun ja nopean kehityksen myötä:

"--- kouluttautumiseen ja osaamisen kehittämiseen kannustetaan, ei me tällaisiin tuloksiin ylletä, jos meillä ei ole hyvä osaaminen. Se on ihan tosi asia. Meidän täytyy olla alan huippuosaajia ja sehän vaatii silloin koulun penkillä istumista." (Vakuutus, viestintäpäällikkö )

Myös vakuutusalan organisaation viestintäpäällikön mukaan huippuosaaminen vaatii kouluttautumista, ja organisaation on siksi myös kannustettava työntekijöitä kouluttautumiseen. Työntekijätkin tiedostavat tämän jatkuvan oppimisen tarpeen:

"Ei voi enää elää niin, että ajattelee, että minä tulin tätä työtä tekemään ja tätä teen täälä niin kauan kun olen, vaan että tilanteet muuttuu ja työtehtävät ja niiden toimenkuvat muuttuu ---" (Vakuutus, kehittämiskonsultti)

Tietotyössä on työntekijöidenkin mielestä hyväksyttävä jatkuvan kehittymisen vaatimus ja elettävä organisaation tarpeiden ehdoilla. Tästä lähtökohdasta tietotyöntekijöiden psykologisen sopimuksen on oltava luonteeltaan joustava ja sisällettävä kehittyminen ja tehtävien muuttuminen. Työnantajan näkökulmasta työntekijöiltä odotetaankin muutos- ja kehitysmyönteistä asennetta: 
"Varmaan suurin haaste tässä työssä on tietynlainen jatkuva uuden oppiminen. Elikkä työkalut, tuotteet, palvelut, yleensäkin tekniikat, kehittyy ja muuttuu. Ja se, että pysyy siinä kehityksessä mukana, niin se on varmasti joillekin haaste. Et se ei ole semmosta, että kun sä nyt olet käynyt koulutuksen ja ollut vähän aikaa puhelimessa niin työ on seuraavat viis vuotta ihan samanlaista, vastata samoihin kysymyksiin." (Call center, Help desk -palvelupäällikkö)

Työnantajapuolella tunnustetaan myös jatkuvan kehittymisen haastavuus. Tekniikan nopea muutos säätelee osaltaan kehittymisen tarvetta, joten työn muuttuminen on väistämätöntä, ja työntekijät eivät voi enää odottaa työtehtävien pysyvyyttä. Call center -työssä muutoksia ja uusia teknisiä ratkaisuja tulee jopa päivittäin. Työnantajapuolen odotukset voivat osaltaan vaikuttaa psykologisen sopimuksen sisältöön (esim. Coyle-Shapiro 2002). Työnantajan vaatimus pysyä kehityksen vauhdissa lisää siten työntekijöiden paineita selvitä työn muuttuvista haasteista.

Kehittymisen tarpeet ovat erilaisia tietotyön eri sektoreilla. Tutkimuksen esimerkkiorganisaatioista T\&K-osasto muodostaa poikkeuksen työn vaativuuden suhteen. Muiden organisaatioiden tapaan työ vaatii jatkuvaa oppimista, mutta työntekijöiden ja johdon jaetun ymmärryksen mukaan työtä ei ole edes mahdollista oppia koulussa tai nopeasti täsmäkoulutuksilla, vaan asiantuntijaksi tullaan vasta vuosien työn kautta:

"Aika tyypillistä meidän organisaatiossa on, että samalla systeemillä tullaan töihin kun mäkin, että kesätöihin, diplomityö ja sitten jä̈ny siitä. -- se tuntuu olevan pysyvämpi tapa, että kesätöiden kautta näkee mikä on homma ja oppii siihen sitä kautta. Se [muodollinen koulutus] antaa pohjan, mutta ei sillain siihen työhön varsinaisesti valmista, että se opitaan sitten täällä työn myötä. ---. Se on sitten omasta aktiivisuudesta kiinni, että kuinka paljon jossain kursseilla haluaa käydä. Kyllä aina on päässy kun on halunnu kursseille mennä, ja välillä vähän kehotetaankin." (T\&K, chief research engineer)
Sekä työntekijät että esimiehet ovat sisäistäneet alansa vaatimukset ja jatkuvan muutoksen tarpeen. Perustehtävien oppiminen voi viedä jopa vuosia, minkä jälkeen edessä on vielä osaamisen päivittäminen. Nämä vaatimukset ovat käyneet T\&K-osaston työntekijöille selviksi jo työharjoittelujaksojen kautta, joten uusien työntekijöiden psykologinen sopimus sisältää jo uuden oppimisen velvollisuuden ja organisaation tarpeiden mukaan kehittymisen.

On kuitenkin varsin ristiriitaista, että organisaation tarpeista lähtevän, korkean tason osaamisen hankkiminen ja ylläpitäminen kouluttautumalla jää käytännössä työntekijöiden järjesteltäväksi. Tässä suhteessa T\&K-osasto on samanlainen kuin muutkin esimerkkiorganisaatiot. Kouluttautuminen on pääasiassa omasta aktiivisuudesta kiinni, vaikka kursseille joskus kehotetaankin. Kaikkien esimerkkiorganisaatioiden aineistoista löytyy työntekijöitä, joiden mukaan koulutukseen "päästään", tai se "suodaan", ja ylipäätään kouluttautuminen on "oma-aloitteista, mutta mahdollista." Työntekijän on oltava aktiivinen sekä koulutuksen tarpeiden pohtimisessa että koulutukseen hakeutumisessa. Työntekijät toimivat enemmän organisaation edun mukaisesti kuin omansa. He tarkkailevat, millaisella kehittymisellä ja koulutuksella selviytyisivät nykyisestä työstään paremmin.

Haastatteluiden perusteella työnantajapuolen odotuksena on psykologinen sopimus, jossa työntekijän velvollisuus on kehittyä organisaation vaatimassa tahdissa. Jatkuva uuden oppiminen haastavana velvollisuutena on jotain muuta kuin työllistyvyys-teesin mukainen, työn epävarmuutta korvaava oikeus.

\section{Työntekijöiden toiveet ja oikeudet}

Organisaation tarpeiden lisäksi työntekijöiden henkilökohtaiset asenteet ja tarpeet vaikuttavat työssä kehittymiseen. Työntekijällä voidaan nähdä olevan myös oikeus kehittymiseen ja kouluttautumiseen eli ne ovat psykologiseen sopimukseen sisältyvä vastine työpanoksesta. Työtaitojen kehittäminen voidaan nähdä välttämättömyytenä ja erottamattomana osana työn luonnetta:

"Kun on näinkin pitkälle kouluttautunut, niin sen jo tietää, että tää vaatii kaiken aikaa vähän koulut- 
tautumista. Työ jo itsessään opettaa paljon, mutta on se hyvä, että voi tarpeen vaatiessa hankkiutua muunkinlaisiin täsmäkoulutuksiin." (Koulutus, suunnittelija)

Pelkkä työtehtävien kautta oppiminen ei kuitenkaan riitä asiantuntijatyössä, vaan työntekijät vaativat myös tehtäviin sopivia koulutuksia. Koulutuksien laadusta on kuitenkin monenlaisia mielipiteitä. Toiset kaipaavat lyhyitä käytännön opastuksia, toisille kouluttautuminen tarkoittaa perusteellisempaa opiskelua. Etenkin call centerissä ja vakuutusyhtiössä kaivattiin toistuvien lyhyiden koulutusten tilalle myös osaamisen laajentamista.

Työntekijät kaipaavat haasteita ja kehittymisen paikkoja myös, koska kokevat niiden lisäävän työssä viihtymistä ja palvelevan omaa urakehitystään:

"--- työ on kuitenkin aika vapaamuotoista, että pystyy itse aika pitkälti miettimään, että minkälaisessa projektissa mä haluan tehdä töitä ---. Ett ei ole tämmöistä, että sulle osoitetaan tai ehdotetaan kovin pitkälle, että tällaisia projekteja sä nyt teet vaan voi itse hakea aktiivisesti uusia hankkeita semmoisista aiheista, joista on itse kiinnostunut. Ja silloin se työmotivaatio ja kiinnostus siihen työhön on paljon suurempi." (Koulutus, koulutussuunnittelija.)

Työn haastavuus ja haasteiden kautta kehittyminen on erittäin tärkeää tietotyöntekijöille. Työntekijät toivovat voivansa työskennellä mieluummin kykyjensä ylärajalla, oppien jatkuvasti uusia asioita. Toivetta perustellaan sillä, että työn haasteet tekevät työstä mielekkäämpää. Yhden mielestä "työntaso heikkenee, kun tekee samantyyppistä tehtävää, niin sit ei jaksa innostua” ja toinen pelkää että edessä on "väsähtäminen siihen, jos menee liian suppeaksi osaaminen." Työntekijät etsivät myös itse aktiivisesti kehittymisen mahdollisuuksia sen lisäksi, että organisaation suunnalta odotetaan kehittymistä.

Esimiesten mielestä työntekijöiden kehittyminen ja kouluttautuminen saakin jäädä työntekijöiden itsensä hoidettavaksi:

"- me korostetaan, että tällaisessa työssä se on työntekijänkin tehtävä pitää sitä omaa ammattitaitoa yllä, ett kyl se aika paljon tulee sieltä, ett ihmiset esittää tietynlaista koulutusta ja osaamista haluttais ja sitten keskustellaan. Mut kyllä mä joskus, jos tulee joku koulutus, saatan jollekin sanoa, että tää sopis sulle. Mut ei voi sanoa, että se olis systemaattista. Mut sitten, kun ihmiset esittävät niitä omia tarpeitaan, niin niihin suhtaudutaan ihan positiivisesti." (Koulutus, johtava suunnittelija.)

Edellä lainatun koulutusorganisaation johtavan suunnittelijan mukaan työntekijän itsensä tulee olla aktiivinen toimija ammattitaitonsa ylläpitämisessä. Johdon tehtäväksi jää suostumuksen antaminen tai parhaimmillaan koulutuksen suosittelu. Koulutustoiveisiin "positiivisesti suhtautuminen" kertoo työntekijän oikeudesta kehittymiseen, mutta voimakkaammin esimies painottaa työntekijän velvollisuutta huolehtia ammattitaidostaan. Aikuiskoulutusorganisaatiossa sekä esimiehet että työntekijät pitivät työntekijöiden kouluttautumista luontevana osana työtä jo organisaation toimialankin takia.

Kouluttautumisen nähdään kertovan myös työntekijän sitoutumisesta ja halusta edetä organisaatiossa:

"Yleensä täällä on esimiestasolla sanottu, että jos jonkun kurssin keksit, ni saat mennä. Ja nytkin on olemassa tällänen vuosikoulutussuunnitelma, että ehdottomasti näitten pitäs käydä nää ja nää... Mutta kuitenkin jotenkin tuntuu, että se [kouluttautuminen] on ihmisten omasta aktiivisuudesta kiinni, ja jotkut ihmiset on aktiivisia kouluttautumaan. Ja ne on yleensä niitä ihmisiä, jotka sitten urallaankin etenee. Mutta väittäisin, että kursseille pääsee, mutta jos vähänkin on innostusta, niin koulutetaan, ja jos tuote vaatii niin sit koulutetaan. Mutta ehkä vielä enemmän sais tätä kannustustakin olla." (T\&K, tuotekehitysjohtaja)

Vaikka organisaatiossa tehdään koulutussuunnitelmia, niistä huolimatta kouluttautuminen voi jäädä työntekijöiden vastuulle. Tuotekehitysjohtajan mukaan aktiivisuus kouluttautumisessa kertoo usein myös uralla etenemisestä. Onko siis niin, että koska kouluttautuminen hyödyttää työntekijää itseään urakehityksen muodossa, työntekijöillä on vastuu kouluttautumisesta? Molemmat edellä lainatut esi- 
miesten haastattelut viittaavat siihen että esimiesten pitäisi olla vastuussa ammattitaidon kehittämisestä, mutta käytännössä työntekijöiden tulee valvoa omia oikeuksiaan, eli toimia aktiivisesti oman ammatillisen kehittymisensä hyväksi. Vastuu omasta ammatillisesta kehittymisestä on tietotyöntekijöillä itsellään. Tämä kertoo tietotyön autonomisesta luonteesta ja itsensä johtamisesta, mutta samalla kehittymisestä yhtenä lisävastuuna, josta työntekijät huolehtivat.

\section{Vastavuoroisuus: työntekijöiden ja organisaation yhteinen etu}

Vastavuoroisessa vaihdossa kummatkin osapuolet eli organisaatio ja työntekijät hyötyisivät työntekijöiden kehittymisestä, eli psykologisen sopimuksen velvollisuudet ja oikeudet tulisivat täytettyä. Vastavuoroisuuden esteenä voivat kuitenkin olla johdon ja alaisten toisistaan poikkeavat käsitykset siitä, mikä on työssä kehittymistä:

"Me hämmästyttiin ett miksi meidän ihmiset vastaa voimavarakyselyissä just tähän kysymykseen, että koetko oppivasi ja kehittyväsi tässä työssä, aina niin huonosti, negatiivisesti. Ja sit me kysyttiin, ett kun sä koko ajan joudut oppimaan uutta ja saat oppia uutta, niin eiks se oo kehittymistä? "Ei kun se on lisätyötä." Että en tiedä miten sitä motivois tällä hetkellä, mut mä yritän täällä löytää keskustelemalla ihmisten kanssa siihen jonkun näköistä ratkaisua, ett miten me se tehtäis, jotta ihmiset kokis kehittyvänsä ---." (Call center, henkilöstöjohtaja)

Telealan organisaatiossa on uskottu, että henkilökunnan oppimisen ja kehittymisen tarpeet on täytetty, mutta työntekijät ovatkin kokeneet joutuvansa tekemään lisätyötä opetellessaan uusia taitoja. Vastavuoroisuuteen pyrkiminen voi johtaa tilanteeseen, jossa työntekijät kokevat, että heidän oikeuttaan kehittymiseen ei ole huomioitu. Kun pyritään vastaamaan työntekijöiden kehittymistarpeisiin organisaation osaamistarpeiden puitteissa, on henkilökuntaa kuunneltava, jotta vastavuoroisuus saavutettaisiin.

Työntekijöiden puolelta tällaiset tilanteet, joissa kehittymisen tarpeet eivät täyty, voidaan kokea jopa psykologisen sopimuksen rikkoutumisena. Vastaa- vassa tilanteessa vakuutusyhtiön työntekijä kertoo pettyneensä kehittymismahdollisuuksiin:

"Työssä menee niin paljon aikaa siihen itse työhön, ett se itsensä kehittäminen, niin se on vähän kyl... Silloin kun aluksi tuli, niin olihan silloin suuret suunnitelmat, että oppii lisää sitä alaa ja sit se koko oppiminen tulee työnteon kautta. Matemaattisella puolella ois niin paljon kaikkee, mitä ei vielä osaa, mielenkiintoista. Se ois sitten vapaa-ajan hommia, mut siel on sit taas muuta." (Vakuutus, aktuaari)

Pettymys liittyy nimenomaan siihen, että oppiminen tulee työn tekemisen kautta, eikä varsinaisten koulutusten kautta. Tämä ei vastaa työntekijän kuvitelmaa työn antamista kehittymismahdollisuuksista. Hän kokee myös, että ammatillinen kehitys ei kuulu vapaa-ajalle, vaan sen tulisi tapahtua työaikana. Järnefeltin $(2002,48)$ mukaan erityisesti melko korkeasti koulutettuja työntekijöitä kannustetaan ammattitaitonsa kehittämiseen, mutta työajan sijaan vapaaajalla, eli kehittymistä ei tunnusteta varsinaiseksi työksi ja työajaksi. Vapaa-ajan käyttäminen työhön kuuluvien taitojen opiskeluun ei sovi uusiin psykologisen sopimuksen malleihin, kuten tasapainotettuun sopimukseen. Tasapainotetun sopimuksen mukaan kouluttautuminen on työntekijän oikeus, joten on luontevaa, ettei työntekijä uhraa siihen vapaa-aikaansa. Laadukkaiden koulutusmahdollisuuksien arvostaminen työn kautta oppimisen lisäksi kertoo myös kehittymisen näkemisestä oikeutena.

Miten organisaation ja työntekijöiden tarpeet sitten saataisiin kohtaamaan ja samalla myös psykologinen sopimus täyttymään? Työntekijäpuolella kehittymiseen kaivataan suunnitelmallisuutta ja pitkäjänteisyyttä:

"Meiltä puuttuu urapolkuajattelu. Et semmosta pitkäjänteistä henkilöstösuunnittelua ei oo tehty. --- tuntuu, että kun joku lähtee talosta tai vaihtaa yksiköstä toiseen talon sisällä, että se on semmosta tulipalojen sammuttamista, että nyt tää paikka pitää täyttää, mistä me nyt otetaan. Jos olis määrätietonen ja suunnitelmallinen urakehityssuunnittelu, niin esimiehellähän olis siihen jo kasvamassa seu- 
raava. Ja se on osa sitouttamista mun mielestä. Jos ihminen näkee tulevaisuuden ja sen, että on mahdollisuuksia hankkia jotain uutta osaamista ja siirtyä tekemään jotain muuta, niin kyl sä viihdyt siellä ihan eri lailla." (Vakuutus, kehittämiskonsultti)

Urapolkujen suunnitteleminen ja toteuttaminen palvelisi työntekijöiden mukaan sekä organisaatiota että tietotyöläisiä. Työntekijöiden kannalta urasuunnittelu lisäisi motivaatiota, mutta samalla organisaatiokin hyötyisi henkilöstösuunnittelun ennakoitavuudesta. Vakuutusorganisaation haastatteluissa painotettiin alan kovaa kilpailua ja henkilöstön suurta merkitystä kilpailussa pärjäämisessä, joten urasuunnittelu nähtiin yhtenä kilpailutekijänä. Sekä vakuutus- että muidenkin organisaatioiden haastatteluissa tuli esiin myös ns. mestari-kisälli-malli, jossa konkarityöntekijät siirtävät osaamistaan kollegoilleen. Siinäkin työntekijät kehittyisivät ja samalla organisaatio hyötyisi hiljaisen tiedon siirtymisestä aina uusille työntekijöille.

Pitkän tähtäimen suunnittelun tarve tunnistetaan myös johdossa:

"-- mun mielestä ois tosi kannustavaa ja sitouttavaa ja jos mulle heti kun mä tulen taloon kerrottais, ett nyt kun sä oot täällä ollut ton aikaa, meet tommoseen koulutukseen ja jonka jälkeen nää vois olla seuraavii steppei sun työuralle. Niin mä näkisin jo siinä vaiheessa, ett kun mä teen tätä työtä, mikä ei oo mulle tässä vaiheessa kiinnostavaa, mut mä tiedän, etten mä tätä työtä kuitenkaan välttämättä halua koko uraani tehdä, voisin niin kun nähdä ne seuraavat stepit, jotka ne sitouttais mut kuitenkin sinne asti. (Call center, palvelupäällikkö)

Esimiehetkin uskovat, että työntekijät pysyisivät talossa paremmin voidessaan suunnitella uraansa pitemmällä tähtäimellä. Koulutuspolkujen suunnittelu jo työsuhteen aikaisessa vaiheessa nähdään sitouttavana ja motivaatiota lisäävänä. Palvelupäällikön mielipide edustaa siinä suhteessa äärilaitaa, että hän näkee urasuunnittelun keinona sitouttaa työntekijöitä jopa vähemmän kiinnostavien uravaiheiden yli, kohti mielekkäämpiä tehtäviä.
Molempien puolten toiveet heijastelevat yllättäen perinteisen eli relationaalisen psykologisen sopimuksen periaatteita: työntekijä tekee työnsä hyvin, kehittää edelleen osaamistaan ja palkkioksi saa pitää työnsä ja jopa edetä urallaan. Aineistossa esitetyt toiveet organisaatioiden urapoluista kertovat psykologisen sopimuksen muuttumisesta tasapainotetun sopimusmallin suuntaan, mutta samalla siinä voidaan havaita edelleen myös relationaalisen psykologisen sopimuksen lojaaliuden ja vastavuoroisuuden arvostusta.

\section{YHTEENVETO JA POHDINTA}

Edellä olen tarkastellut työssä kehittymistä ja oppimista psykologisen sopimuksen osana tietotyössä. Tutkimuksen tulokset eivät puhu yksiselitteisesti sen puolesta, että kehittyminen koettaisiin pelkäksi oikeudeksi. Kehittyminen on edelleen myös organisaatioiden työntekijöilleen asettama velvollisuus, jonka käytännön toteutus on työntekijöiden omalla vastuulla. Kehittymisellä nähdään kuitenkin samalla olevan myös työmotivaatiota ylläpitävä vaikutus.

Työntekijöiden kehittymisen ja kouluttautumisen lähtökohtana ovat edelleenkin organisaation tarpeet työntekijöiden urakehityksen sijaan. Tietotyössä tekniikan kehittyminen ja kilpailussa mukana pysymisen tavoite luovat organisaation kehitystarpeet, joten ne tarvitsevat osaavaa ja kehittymiskykyistä henkilökuntaa. Tästä näkökulmasta osaamisen voisi ajatella olevan työntekijöiden valuuttaa ja kilpailutekijä, mutta seurauksena onkin työntekijöiden velvollisuus kehittyä ja kouluttautua. Työntekijätkin tiedostavat tämän lähtökohdan, joten kehittymisvaatimuksia pidetään luonnollisena osana tietotyötä, vaikka jatkuva uuden opetteleminen olisi välillä raskasta. Kehittymisen rooli psykologisessa sopimuksessa voi rakentua jo ennen työn aloittamista ja vahvistua edelleen työsuhteen aikana velvollisuudeksi, jos organisaation puolelta korostetaan voimakkaasti sen velvollisuusluonnetta.

Kehittymisen koetaan olevan toisaalta olennainen osa tietotyön mielekkyyttä ja se merkityksellistetään työntekijän oikeudeksi. Tämän oikeuden toteuttaminen, eli kehittymismahdollisuuksin etsiminen ja kouluttautumisen suunnittelu, on kuitenkin käy- 
tännössä työntekijän velvollisuus. Työnantajapuolen tehtäväksi jää lähinnä koulutussuunnitelmien hyväksyminen, vaikka molemmat osapuolet pitävät koulutussuunnittelua periaatteessa työnantajapuolen velvollisuutena. Kehittymistä voidaan siis pitää myös psykologiseen sopimukseen kuuluvana oikeutena, mutta työntekijä on siinäkin tapauksessa velvollinen huolehtimaan itse omien oikeuksiensa toteutumisesta. Tässä suhteessa psykologisen sopimuksen patriarkaalinen henki on unohdettu, joten ne, jotka toivovat työnantajan valvovan etujaan, voivat joutua pettymään.

Ristiriitatilanteita kehittymistoiveiden täyttämisessä voi aiheutua myös, jos osapuolten käsitys kehittymisen sisällöstä on erilainen. Jotta psykologisen sopimuksen rikkomiselta vältyttäisiin, organisaatioiden olisi pystyttävä tarjoamaan työntekijöilleen sellaisia kehittymis- ja oppimismahdollisuuksia, joista työntekijät kokevat olevan hyötyä joko nykyisissä työtehtävissä tai tulevaa urakehitystä silmällä pitäen. Sekä työntekijöiden että esimiesten ratkaisuna tähän ehdotettiin erilaisia organisaation sisäisiä urasuunnitelmia. Sekä esimiehillä että työntekijöillä on toiveena sellainen työntekijöiden kehittyminen, joka palvelisi samanaikaisesti sekä työntekijöiden viihtymistä että organisaation toiminnan tehokkuutta ja jatkuvuutta. Nämä toiveet kuulostavat yllättäen relationaalisen psykologisen sopimuksen määritelmän mukaisilta. Työntekijät ovat valmiita kehittymään organisaation tarpeiden mukaisesti, jos myös työntekijät hyötyvät siitä. Kehittyminen voi olla tietotyöntekijöille merkittävä mahdollisuus, jonka hyödyntämiseen työntekijöiden kannattaisi kiinnittää nykyistä enemmän huomiota. Samalla työnantajien tulisi yhä paremmin mahdollistaa työntekijöiden kehittyminen, jotta suomalaisella työelämällä olisi mahdollisuus saavuttaa artikkelin alussa mainitut ministeriöiden (TEM 2012; OKM 2010) hahmottelemat tavoitteet.

Yksi erityisesti tietotyöntekijöiden psykologisille sopimuksille ominainen sisältö on toive siitä, että voi tehdä työnsä hyvin ( ${ }^{\prime}$ Donohue ym. 2007). Muuttuvassa työssä pärjääminen ja työn hyvin tekeminen vaativat kehittymistä. Kehittyminen on tämän tutkimuksen perusteella tärkeä osa tietotyötä ja sen psykologista sopimusta. Kehityksen merkityksessä voidaan havaita eroja paitsi tuotanto- ja tietotyöntekijöiden välillä (Martin ym. 1998) myös tietotyön eri tyyppien välillä. Tietotyön määritelmä käsittää hyvin kirjavan joukon ammattialoja ja työtehtäviä, joissa työskentelevillä voi olla merkittävästi toisistaan eroavia psykologisia sopimuksia. Eri aloilla on toisistaan poikkeavat pohjakoulutus- ja osaamisvaatimukset (vrt. esim. call center ja T\&K) ja myös organisaatioiden tarpeet kehittymiselle (vrt. vakuutus- ja aikuiskoulutusalojen erilaiset kilpailuasemat).

Tulosten pohjalta voidaan väittää, että kehittyminen on tietotyön arjen tasolla pikemminkin velvollisuus kuin oikeus. Tämän tutkimuksen organisaatioissa kehitystä sinänsä ei vastusteta, mutta kehityksen toivotaan lähtevän enemmän työntekijöiden tarpeista ja lähtökohdista (vrt. Järvensivu \& Koski 2012). Kun näin ei ole, kehitys ja kouluttautuminen koetaan velvollisuutena. Se, että työntekijöiden ja työnantajapuolen käsitykset hyödyllisestä ja motivoivasta kehittymisestä ja kouluttautumisesta eivät aina kohtaa, eli työntekijä joutuu kehittymään työnantajan ehdoilla, voidaan kokea myös psykologisen sopimuksen rikkomisena (ks. myös Martin ym. 1998).

Teesi turvallisuuden korvaamisesta työllistyvyydellä (Rajan 1997; Martin ym. 1998; Alasoini 2006, 2012) ei siis vielä täysin toteudu tietotyön saralla. Vaikka kehittyminen olisi mielekästäkin, se ei ainakaan vielä korvaa toivetta työn jatkuvuudesta. Kehittyminen mielletään yhdeksi velvollisuudeksi muiden työtehtävien joukossa, eikä palkinnoksi sinänsä. Työntekijät kaipaavat työsuhteiltaan jatkuvuutta eivätkä koe kehittymismahdollisuuksia yhtä merkittävänä tekijänä työsuhteen vaihtokaupassa kuin turvallisuutta (ks. myös Baruch 2001; Scholarios ym. 2008). Työllistyvyys-teesin vastaisesti työntekijät voivat jopa odottaa työnantajiltaan jotain vastineeksi kehittymiseen käytetystä ajasta ja vaivasta. Odotuksissa saattaa olla, täysin perinteisen psykologisen sopimuksen mukaisesti, työn jatkuminen. 
Tiina Saari

YTM, tutkija, jatko-opiskelija

Yhteiskunta- ja

kulttuuritieteiden yksikkö

Tampereen yliopisto
Kiitokset: Kiitän Harri Meliniä, Eriikka Oinosta ja Pasi Pyöriää ohjauksesta sekä kahta refereetä kommenteista. Tutkimusta on rahoittanut Emil Aaltosen säätiö.

1 Aineisto on kerätty Suomen Akatemian rahoittamassa Successful organizations and employee well-being in knowledge-intensive workprojektissa.

\section{KIRJALLISUUS}

Alasoini, T. (2006). Työnteon mielekkyyden muutos Suomessa vuosina 1992-2005. Työolobarometrin aineistoihin perustuva analyysi. Tykes raportteja 45 . Helsinki: Tykes.

Alasoini, T. (2012). Psykologinen sopimus organisaation ja työntekijöiden yhteisenä etuna. Teoksessa Pyöriä P. (toim.) Työhyvinvointi \& organisaation menestys. Helsinki: Gaudeamus, 99-118.

Aro, M. (2006). Työsuhteiden epävakaistumien ja työssäoppimisen edellytykset. Teoksessa Mäkinen, J., Olkinuora, E., Rinne, R. \& Suikkanen, A. (toim.) Elinkautisesta työstä elinikäiseen oppimiseen. Jyväskylä: PS-Kustannus, 203-220.

Bain and Taylor (2000). Entrapped by the"electronic panopticon"? Worker resistance in the call centre. New Technology, Work and Employment 15(1), 2-18.

Bal, P., Jansen, P., van der Velde M., de Lange A. \& Rousseau, D. (2010). The role of future time perspective in psychological contracts: A study among older workers. Journal of Vocational Behavior 76(3), 474-486.

Baruch, Y. (2001). Employability: a substitute for loyalty? Human Resource Development International 4(4), 543-566.

Benner, C. (2002). Work in the new economy. Flexible Labor Markets in Silicon Valley. Malden, MA: Blackwell Publishing.

Blau, P. (1964). Exchange and Power in Social Life. Chichester: John Wiley and Sons.
Blom, R., Melin, H. \& Pyöriä, P. (2001). Tietotyö ja työelämän muutos. Palkkatyön arki tietoyhteiskunnassa. Helsinki: Gaudeamus.

Conway, N. \& Briner, R. (2005). Understanding the Psychological Contracts at work. A Critical Evaluation of Theory and Research. New York: Oxford University Press.

Coyle-Shapiro, J. \& Kessler, I. (2002). Exploring reciprocity through the lens of the psychological contract: employee and employer perspectives. European Journal of Work and Organizational Psychology 11(1), 69-86.

De Cuyper, N., Van der Heijden, B. \& De Witte, H. (2011). Assocations between perceived employability, employee well-being and it's contribution to organizational success: a matter of psychological contracts? The International Journal of Human Resource Management. 22(7), 1486-1503.

Flood, P. C., Turner, T., Ramamoorthy, N. \& Pearson, J. (2001). Causes and consecuenses of psychological contracts among the high technology and financial services industries. International Journal of Human Resources Management 12(7), 1152-1165.

Järnefelt, N. (2002). Työkiireen syiden jäljillä. Teoksessa Järnefelt, N. \& Lehto, A-M. (toim.) Työhulluja vai hulluja töitä? Tutkimus kiirekokemuksista työpaikoilla. Tutkimuksia 235. Helsinki: Tilastokeskus, 17-56.

Järvensivu, A. \& Koski, P. (2012). Combating learning. Journal of Workplace Learning 24(1), 5-18. 
Jääskeläinen, A. (2011). How to measure and manage the risk of losing key employees? International Journal of Learning and Intellectual Capital 8(1), 63-75.

Krippendorf, K. (2004). Content analysis. An introduction to its methodology. Thousand Oaks, CA: Sage.

Lehto, A-M. (2010). Ovatko työurat muutoksessa? Talous \& yhteiskunta 38(1), 5-14.

Lehto, A-M. \& Sutela, H. (2008). Työolojen kolme vuosikymmentä. Työolotutkimusten tuloksia 19772008. Helsinki: Tilastokeskus

Martin, G., Staines, H. \& Pate, J. (1998). Linking job security and career development in a new psychological contract. Human Resource Management Journal 8(3), 20-40.

Multisilta, J. \& Paajanen, M. (2006). Tietotyön tuottavuus ja työssä oppiminen. Teoksessa Jokivuori, P., Latva-Karjanmaa, R. \& Ropo, A. (toim.) Työelämän taitekohtia. Työpoliittinen tutkimus 309. Helsinki: Työministeriö, 179-199.

Ng, T. \& Feldman, D. (2008). Can you get a better deal elsewhere? The effects of psychological contract replicability on organizational commitment over time. Journal of Vocational Behavior 73(2), 268-277.

Parzefall, M-R. (2008). Psychological contracts and reciprocity: a Study in Finnish context. The International Journal of Human Resource Management 19(9), 1703-1719.

Ojala, S. \& Hautaniemi, A. (2012). Tietotyöntekijän paremmat työmarkkinat? Yhteiskuntapolitiikka 77(5), 479-493.

Opetus- ja kulttuuriministeriö (2010). Elinikäinen oppiminen - mahdollisuus kasvuun ja työllisyyteen. Elinikäisen oppimisen neuvoston ohjelmajulistus. http://www.minedu.fi/OPM/ Koulutus/aikuiskoulutus_ja_vapaa_sivistystyoe/ elinikaisenoppimisenneuvosto/. (Viitattu 1.11.2012.)

Rajan, A. (1997). Employability in the finance sector: rhetoric vs. reality. Human Resource Management Journal 7(1), 67-78.

Rousseau, D. (1995). Psychological contracts in organizations. Understanding written and unwritten agreements. Thousand Oaks, CA: Sage.
Scholarios, D., Van der Heijden, B., Van der Schoot, E., Bozionelos, N., Epitropaki, O., Jedrzejowicz, P., Knauth, P., Marzec , I., Mikkelsen, A. \& Van der Heijde, C. (2008). Employability and the psychological contract in European ICT sector SMEs. The International Journal of Human Resource Management 19(6), 1035-1055.

Seeck, H. \& Parzefall, M-R. (2008). Employee agency: Challenges and opportunities for psychological contract theory. Personnel Review 37(5), 473-489.

Sieben, I. (2007). Does training trigger turnover - or not? Work, Employment \& Society 21(3), 397-416.

Smithson, J. \& Lewis, S. (2000). Is job insecurity changing the psychological contract? Personnel Review 29(6), 680-698.

Sturges, J., Guest, D., Conway, N. \& Mackenzie Davey, K. (2002). A longitudinal study of the relationship between career management and organizational commitment among graduates in the first ten years at work. Journal of Organizational Behavior 23(6), 731-748.

Suikkanen, A., Martti, S. \& Huilaja, H. (2006). Nuorten aikuisten elämänkulku ja sosiaaliset valinnat. Teoksessa Mäkinen, J. \& Olkinuora, E. \& Rinne, R. \& Suikkanen, A. (toim.) Elinkautisesta työstä elinikäiseen oppimiseen. Jyväskylä: PS-Kustannus, 103-120.

Tulkki, P. \& Honkanen, P. (1998). Valta oppimisen kentällä. Teoksessa Silvennoinen, H. \& Tulkki, P. (toim.) Elinikäinen oppiminen. Gaudeamus: Tampere, 25-60.

Tuomi, J. \& Sarajärvi, A. (2002). Laadullinen tutkimus ja sisällön analyysi. Helsinki: Tammi.

Työ- ja elinkeinoministeriö (2012). Työelämän kehittämisstrategia vuoteen 2020. http://www.tem.fi/ index.phtml?C=102073\&s $=4311 \& x$ mid $=4830$. (Viitattu 1.11.2012.)

De Vos, A. \& Buyens, D. \& Schalk, R. (2003). Psychological contract development during organizational socialization: adaptation to reality and the role of reciprocity. Journal of Organizational Behavior 24(5), 537-559. 